\title{
Tropical Cyclone Genesis in the Western North Pacific
}

\author{
By William M. Gray \\ Department of Atmospheric Science, Colorado State University \\ (Manuscript received 27 January 1977, in revised form 27 July 1977)
}

\begin{abstract}
The author has recently completed a global analysis of tropical cyclone genesis (Gray, 1975a). This paper applies the results of that study to a more detailed analysis of tropical cycline genesis in the western North Pacific and of the variation in the seasonal climatology of genesis location and frequency.

The first part of this paper presents statistical information on the seasonal frequency of tropical cyclone genesis and discusses the major physical requirements of genesis. The second part of this paper shows how these hypothesized genesis requirements are specified by the product of six seasonally averaged meteorological parameters. The last part of this paper shows how well the product of these seasonally averaged parameters is related to cyclone genesis location and frequency. A cyclone genesis forecast index is proposed.
\end{abstract}

\section{Background and Purpose}

It is important that the best possible tropical cyclone climatology be compiled for the western North Pacific. This research has been organized with the purpose of imparting maximum climatological and statistical information so that more accurate planning and forecasting decisions can be made regarding western North Pacific tropical cyclone genesis. This paper attempts to establish a physical basis for understanding the processes of seasonal tropical cyclone genesis frequency in this region and of the variation in the seasonal climatology of genesis location and frequency. This is accomplished through an integration of our present observational information and through consideration of the likely relevant physical processes.

\section{Genesis Statistics}

Figure 1 gives the geographic location of the initial detection points of tropical disturbances which later became typhoons or tropical storms during the period of 1946-1973. ${ }^{1}$ Boxes surround 90 and 50 percent of these points, and

1 Tropical cyclones are divided into two categories based on their maximum sustained low level winds: 1) tropical storms with speeds between 34 and 63 knots; and 2) typhoons with speeds greater than 63 knots. the centroid of all points is indicated by the 'C'.

Figure 2 shows the initial locations of the centers of satellite observed trade-wind mesoscale cloud clusters $\left(4^{\circ}\right.$ to $6^{\circ}$ latitude on a side) which later became typhoons during the seven years of 1967-1973. Note that the centroid of the initial cloud disturbance areas as determined by the satellite (point $C$ ) is approximately $4^{\circ}$ longitude further east than the centroid of the initial detection points of disturbances (point B) determined by the Joint Typhoon Warning Center (JTWC) from convectional information. As was expected, the satellite data relocated farther east the initial detection points of disturbances from which tropical cyclones form. It takes the initial cloud cluster disturbance an average of 2-3 days to reach typhoon intensity (Zehr, 1976).

Figures 3 through 6 portray selected monthly (December through March are each treated as one period) locations of the initial cloud systems or wind perturbations from which tropical cyclones later grew, as determined from JTWC data. Solid dots represent tropical cyclones which reached typhoon intensity, and x's represent tropical cyclones which reached only tropical storm intensity. Because of earlier period cyclone intensity determination difficulties, due to lack of satellite reports and accurate aircraft wind measuring equipment, plus the tendency to overintensify systems when other data is 


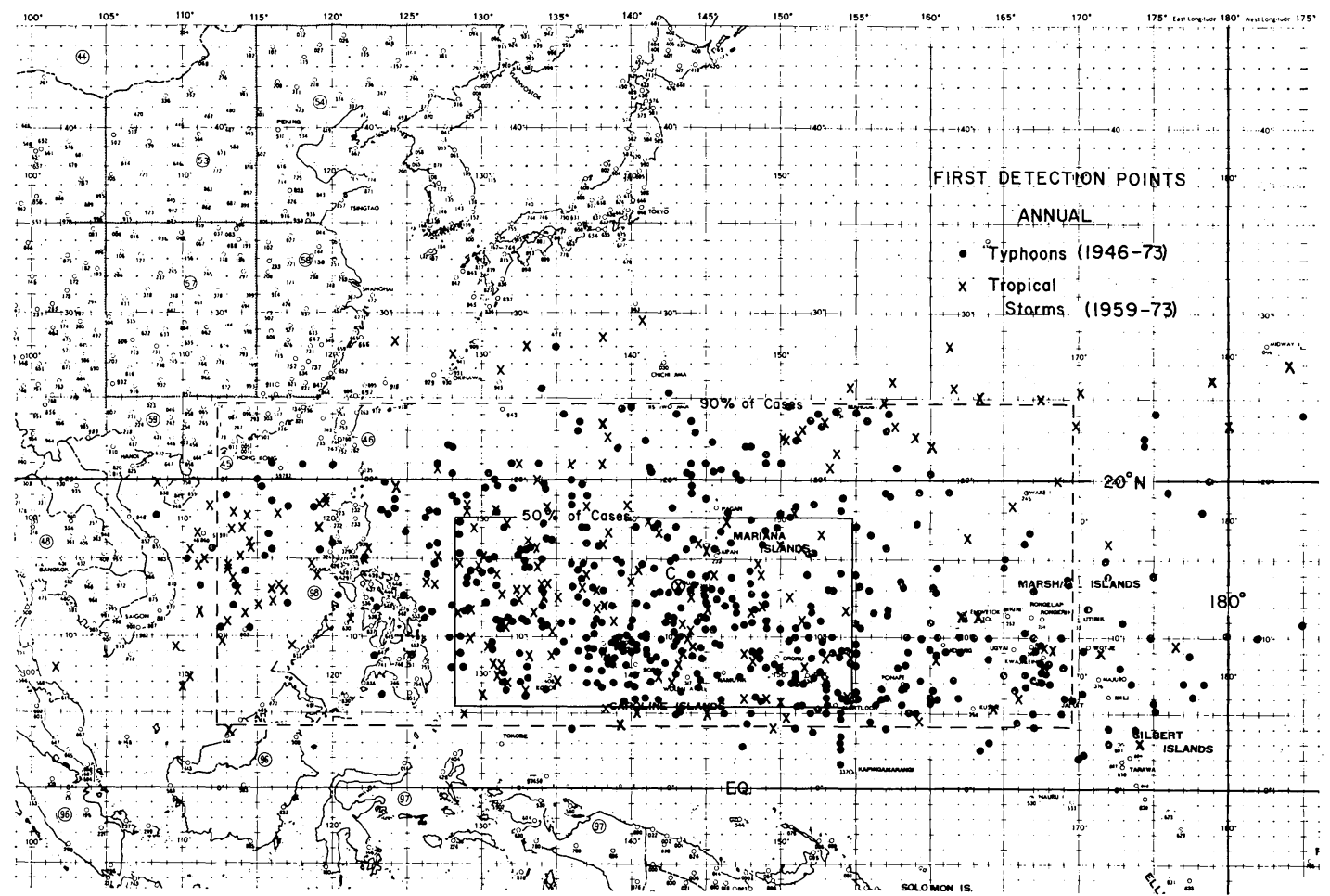

Fig. 1 Initial detection points of tropical systems which later grew to typhoon intensity (solid dots) for years 1946-1973 or of iesser intensity cyclones (x's) for the years 1959-1973. Solid and dotted lines outline 50 and 90 percent of all cases respectively. $\mathrm{C}$ denoted centroid of all points.

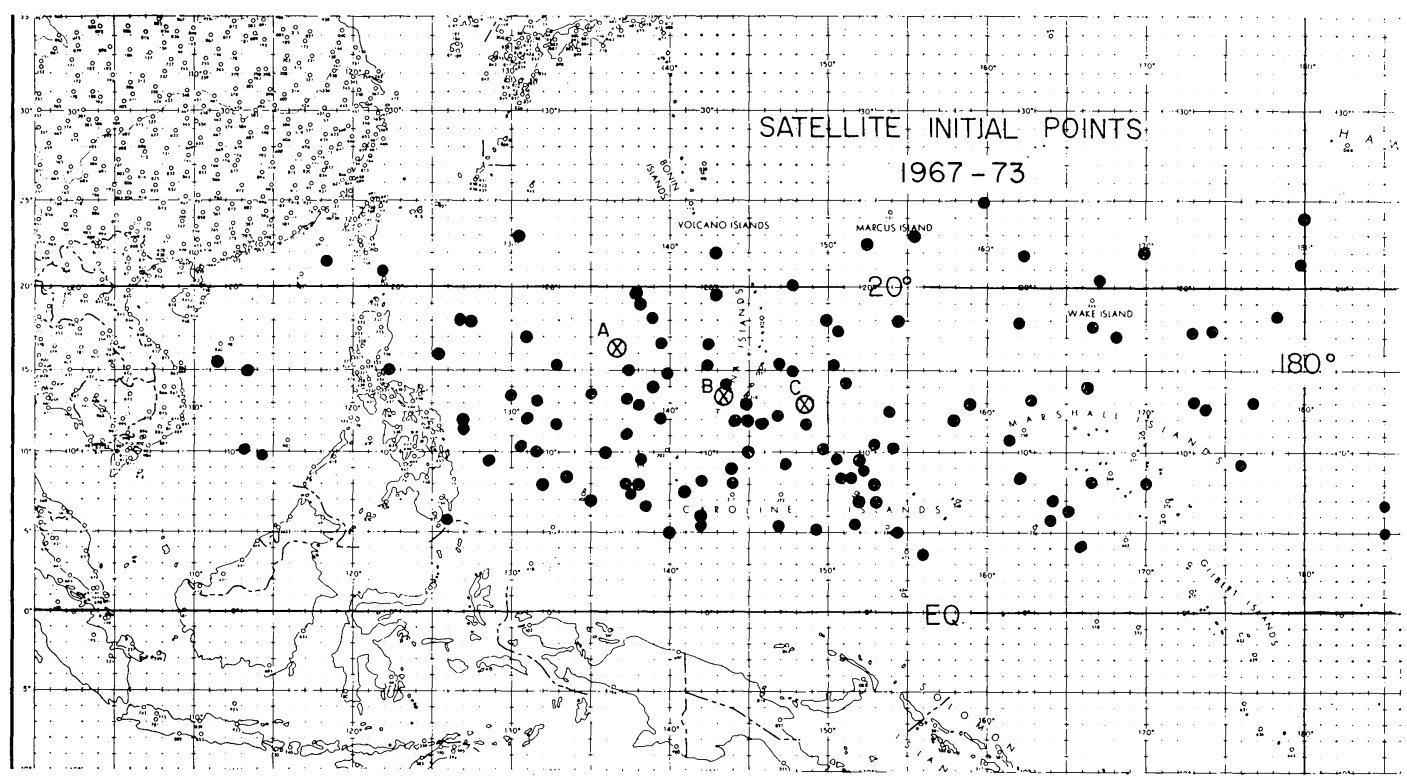

Fig. 2 Satellite determined initial typhoon and tropical storm origin points for a seven year period when satellite data has been available. The $\mathrm{A}$ is the centroid of all the 1946-73 JTWC initial typhoon intensity points, B is the centroid of all the JTWC first detection points for $1946-73$, and $C$ is the centroid of all satellite determined initial detection points for 1967-73. 


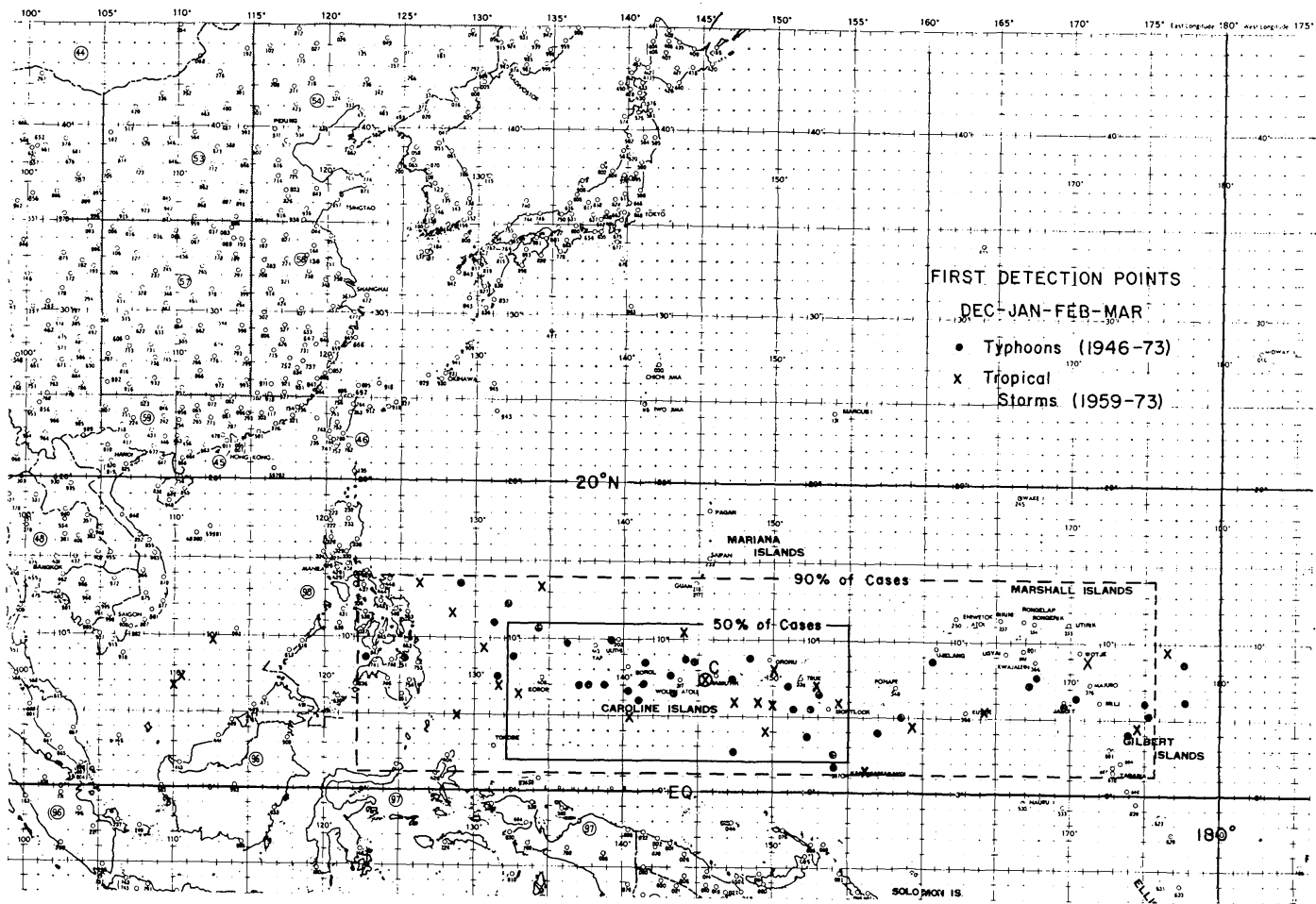

Fig. 3 December-January-February-March initial detection points of tropical systems which later grew to typhoon intensity (solid dots) or to cyclones of lesser intensity (x's). Solid and dotted lines outline 50 and 90 percent of all cases respectively. $\mathrm{C}$ denotes the centroid of all points.

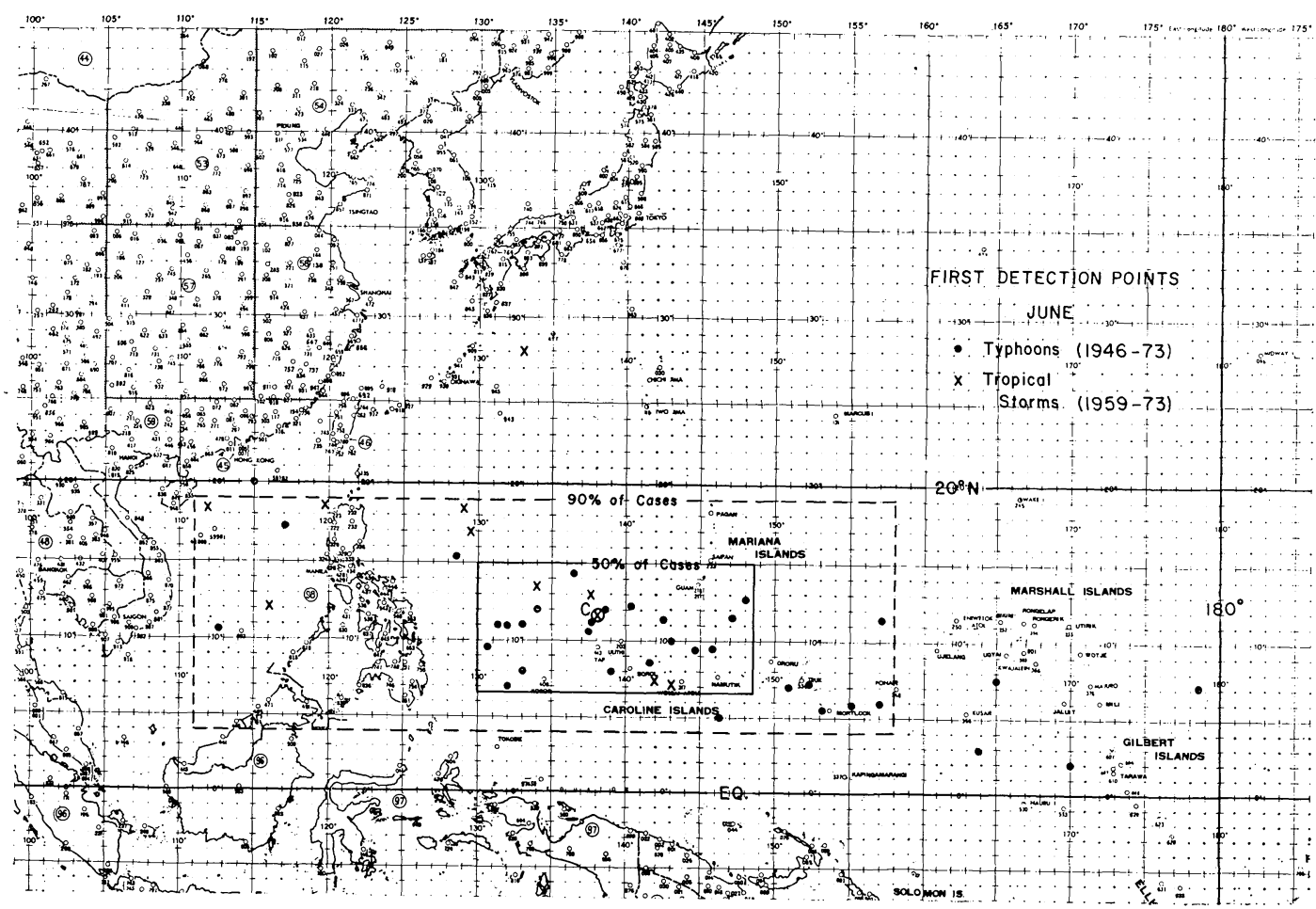

Fig. 4 Same as for Fig. 3 but for the month of June. 


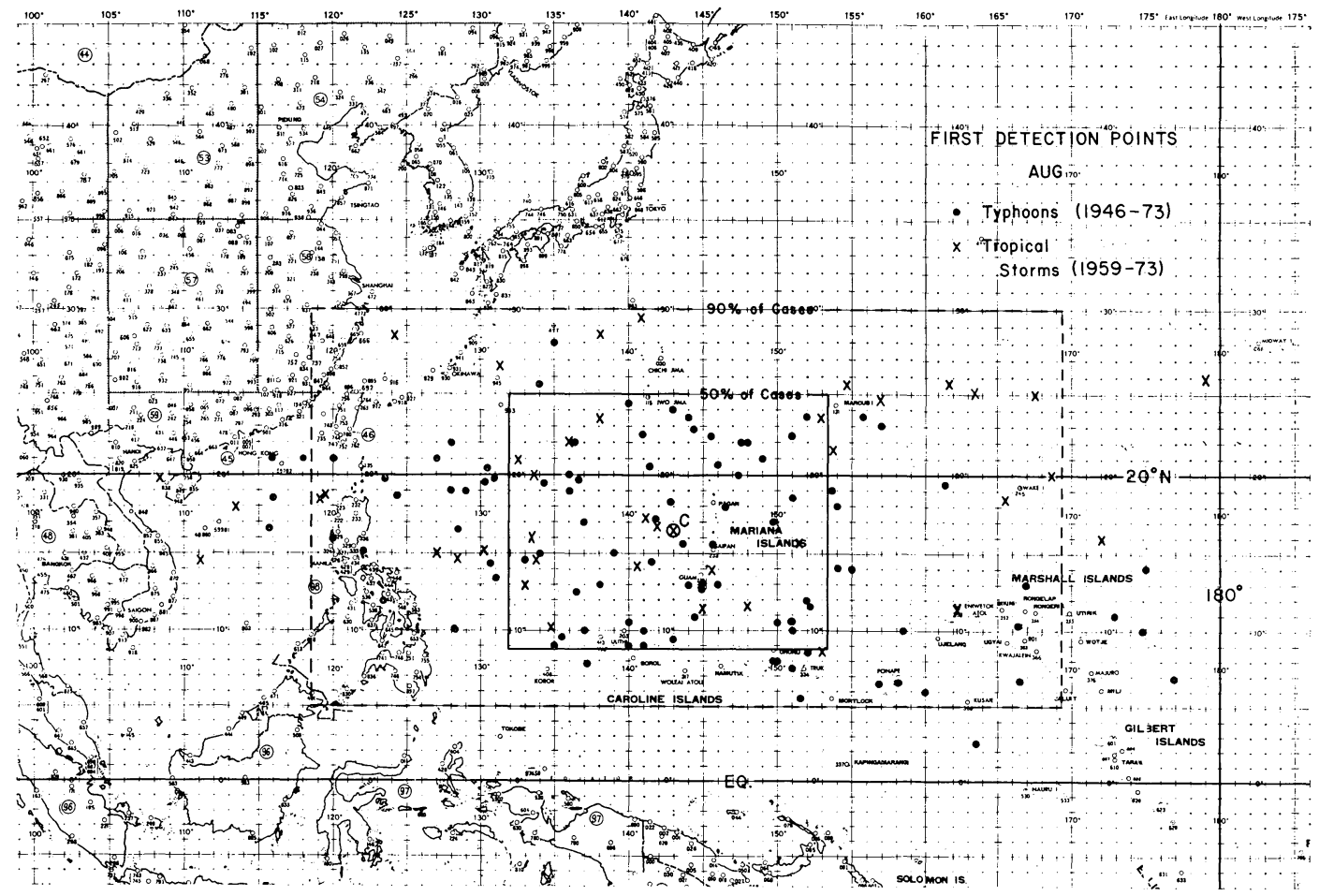

Fig. 5 Same as for Fig. 3 but for the month of August.

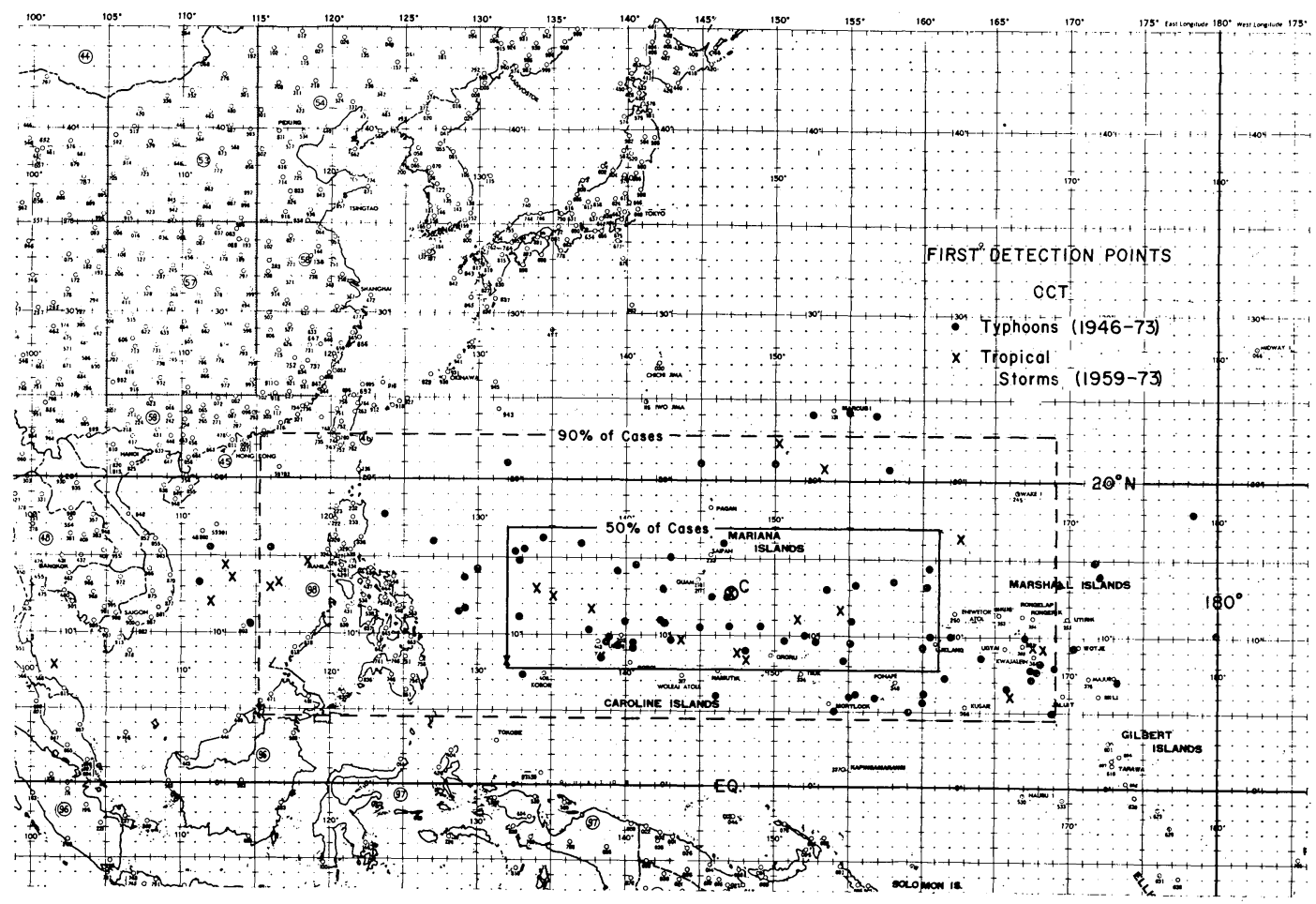

Fig. 6 Same as for Fig. 3 but for the month of October. 
lacking, etc., many weaker tropical cyclones were missed or sometime classified as typhoons. The tropical storm data is thus felt to be representative only since about 1959 or 1960 . Information on these latter intensity disturbances is presented only for this latter period. The ' $\mathrm{C}$ ' denotes the centroid of all points. Little difference can be seen in the initial detection points of the two cyclone groups ( $x$ 's and dots).

Because of observational limitations and the fact that the maximum wind speed of many tropical cyclones is near the 64 knot speed requirement, one cannot with certainty determine the exact number of typhoons and tropical storms for each season. If such classification errors are largely random (as is believed), then one can say

Table 1. Number of Typhoons ( $\geq 64 \mathrm{kt}$ ) and Tropical Storms (34-63 kt) Per Year for the Periods 1946-1958 and 1959-1973.

\begin{tabular}{|c|c|c|}
\hline Year & Typhoons & Tropical \\
\hline & & Storms \\
\hline 1946 & 13 & 2 \\
\hline 1947 & 19 & 8 \\
\hline 1948 & 15 & 11 \\
\hline 1949 & 14 & 8 \\
\hline 1950 & 12 & 6 \\
\hline 1951 & 16 & 1 \\
\hline 1952 & 19 & 9 \\
\hline 1953 & 17 & 6 \\
\hline 1954 & 15 & 4 \\
\hline 1955 & 19 & 3 \\
\hline 1956 & 18 & 4 \\
\hline 1957 & 18 & 3 \\
\hline \multirow[t]{2}{*}{1958} & 20 & 2 \\
\hline & 215 & 67 \\
\hline Average (13 years) & 16.5 & 5.2 \\
\hline 1959 & 17 & 6 \\
\hline 1960 & 19 & 8 \\
\hline 1961 & 20 & 11 \\
\hline 1962 & 24 & 6 \\
\hline 1963 & 19 & 6 \\
\hline 1964 & 26 & 13 \\
\hline 1965 & 21 & 13 \\
\hline 1966 & 20 & 10 \\
\hline 1967 & 20 & 15 \\
\hline 1968 & 20 & 7 \\
\hline 1969 & 13 & 6 \\
\hline 1970 & 12 & 12 \\
\hline 1971 & 24 & 11 \\
\hline 1972 & 22 & 9 \\
\hline \multirow[t]{2}{*}{1973} & 12 & 9 \\
\hline & 289 & 142 \\
\hline Average (15 years) & 19.2 & 9.5 \\
\hline
\end{tabular}

OVERALL AVERAGE (28 years) $\quad 18.0$ that there were approximately 19 typhoons and 9 tropical storms per year in the western North Pacific in the decade (1964-1973). Table 1 shows a yearly breakdown of typhoons vs. tropical storms since 1946 as given in an updated report of Hodge and McKay (1970) and Gray (1970). Note that the data of the last 15 years has shown an average typhoon and tropical storm increase per year of $3 \frac{1 / 2}{2}$ and 4 respectively. This is probably due to earlier observational deficiencies.

The strong correlation between cyclone genesis and upper tropospheric easterly winds is well established. A study of 10 years of U.S. Navy Fleet Weather Central, Joint Typhoon Warning Center (Guam), Annual Typhoon reports by the author has shown that according to the Guam analysis, $200 \mathrm{mb}$ winds over incipient disturbances which later became typhoons were from the NE, $\mathrm{E}$, or $\mathrm{SE}$ in 123 out of 158 cases. Cyclones seldom form in regions where the upper tropospheric wind is from the west.

With approximately 19 typhoons and another 9 tropical storms per year, the western North Pacific is the most active of the globe's eight tropical cyclone genesis regions (Gray, 1968, 1975a). It accounts for approximately one-third of all the tropical cyclones that form. None of the other seven genesis regions experience even half the number of tropical cyclones that occur in the western North Pacific. For instance, this region produces nearly three times as many tropical cyclones per year as does the Western Atlantic region.

As previously discussed (Gray, 1968) about 8085 percent of all tropical cyclones originate in or just on the poleward side of the Inter-Tropical Convergence Zone (ITCZ). Most of the remainder $(\sim 15$ percent) form in the trade winds at a considerable distance from the ITCZ but usually in association with an upper tropospheric trough to their northwest (Sadler, 1967a, 1967b, 1974). A few hybrid-type of warm-core cyclone systems $(\sim 1-2$ percent) develop in sub-tropical latitudes along stagnant frontal zones. This latter type of cyclone is very a typical and not part of the discussion of this paper.

\section{Six Primary Genesis Parameters}

The author (Gray, 1968, 1975a) has previously discussed the important roles which large magnitude, low-level relative vorticity and small magnitude vertical shear of the horizontal wind play in determining regions of high tropical 
cyclone genesis frequency. Genesis also requires other favorable conditions to be present. A number of authors (Riehl, 1954, and much personal communication, 1957-1962; Fisher, 1958; Malkus and Riehl, 1960; Miller, 1964; Leipper, 1967; Perlroth, 1967, 1969; Leipper and Volgenau, 1972) have previously discussed the very important role which sea-surface temperature and high magnitude ocean thermal energy play in tropical cyclone existance. The necessary role of thermal buoyancy from the surface to middle levels for $\mathrm{Cb}$ convection has been discussed by Palmén $(1948,1957)$, and a number of other researchers. Other authors such as Dunn (1940, 1951) have observed the lack of tropical cyclone development near the equator and have hypothesized the importance of the earth's rotation in the genesis process. The author has also observed the high frequency of cyclone genesis in regions where the seasonal values of middle level humidity are high.

The author believes that seasonal tropical cyclone frequency can be directly related to a combination of six physical parameters which will henceforth be referred to as primary genesis parameters. These parameters are:

1) Low-level relative vorticity $\left(Z_{r}\right)$

2) Coriolis Parameter $(f)$

3) The inverse of the vertical shear $\left(S_{z}\right)$ of the horizontal wind between the lower and upper troposphere, or $1 / S_{z}$.

4) A Sea Surface Factor (STF) or the sea temperature above $79^{\circ} \mathrm{F}$ between the surface and 200 feet ocean depth.

5) Vertical gradient of $\theta_{e}$ between the surface and $500 \mathrm{mb}\left(\partial \theta_{e} / \partial p\right)$.

6) Middle troposphere relative humidity $(\mathrm{RH})$.

It will be shown that western North Pacific seasonal cyclone genesis frequency is well related to the adjusted seasonal magnitude of the product of these six parameters, or

$$
\begin{aligned}
\left(\begin{array}{l}
\text { Seasonal } \\
\text { Genesis } \\
\text { Frequency }
\end{array}\right) & \infty\left(Z_{r}\right) \times(f) \times\left(1 / S_{z}\right) \times(\mathrm{STF}) \\
& \times\left(\frac{\partial \theta_{e}}{\partial p}\right) \times R H
\end{aligned}
$$

Previous authors have emphasized the importance for genesis of one or a few of these parameters. Yanai (1964) has previously surveyed a variety of ideas concerning tropical cyclone genesis. The author believes cyclone genesis is dependent on the magnitude of all of these parameters. The physical role which each of these parameters plays in the genesis process will now be discussed.

\subsection{Role of Low Level Relative Vorticity}

Tropical cyclones require a continuous import of mass, momentum, and water vapor. Deep surface to $400 \mathrm{mb}$ convergence profiles exist with all classes of tropical disturbance (see papers of Williams and Gray, 1973; Ruprecht and Gray, 1976; and Zehr, 1976). This deep inflow produces cyclonic flow spin-up in proportion to the existing environmental vorticity fields. Yanai (1961, 1968) has previously emphasized the necessary importance of vorticity convergence for cyclone genesis. In addition, extra boundary layer convergence from Ekman-type of frictional wind veering is produced in proportion to the existing environmental vorticity field. This type of frictionally driven convergence has been discussed by Charney and Eliassen (1949, 1964) and has been employed by many of the numerical modelers in simulating tropical cyclone growth. The association of surrounding low level vorticity with tropical cyclone frequency and cyclone dissipation over tropical water has also been discussed in project reports by Sartor (1968) and Wachtmann (1968).

It is observed that tropical cyclones form only in regions of large positive low level $(\sim 950 \mathrm{mb})$ vorticity. The larger this low level vorticity, the greater the potential for cyclone genesis. Figure 7 gives seasonal values of $950 \mathrm{mb}$ relative vorticity in values of $10^{-6} \mathrm{sec}^{-1}$ plus 5 units (the data source is given in the appendix). The winter season is taken to be the months of January, February, and March; spring, the months of April, May and June, etc.

Other conditions being favorable and remaining constant, tropical cyclone genesis should be directly related to the magnitude of lower tropospheric relative vorticity.

\subsection{Role of Earth's Rotation (i.e. Coriolis Parameter)}

Cyclones do not form within $4-5^{\circ}$ of the equator. The influence of the earth's rotation would thus appear to be of primary importance. A number of previous researchers have stressed this relationship. Except for places where strong meridional flow and import of momentum from higher latitudes is occurring, winds on the equator are very weak. Geostrophic considerations dictate that pressure gradients near the equator be very weak.

Cyclone intensification cannot occur if strong pressure gradients cannot be maintained against 

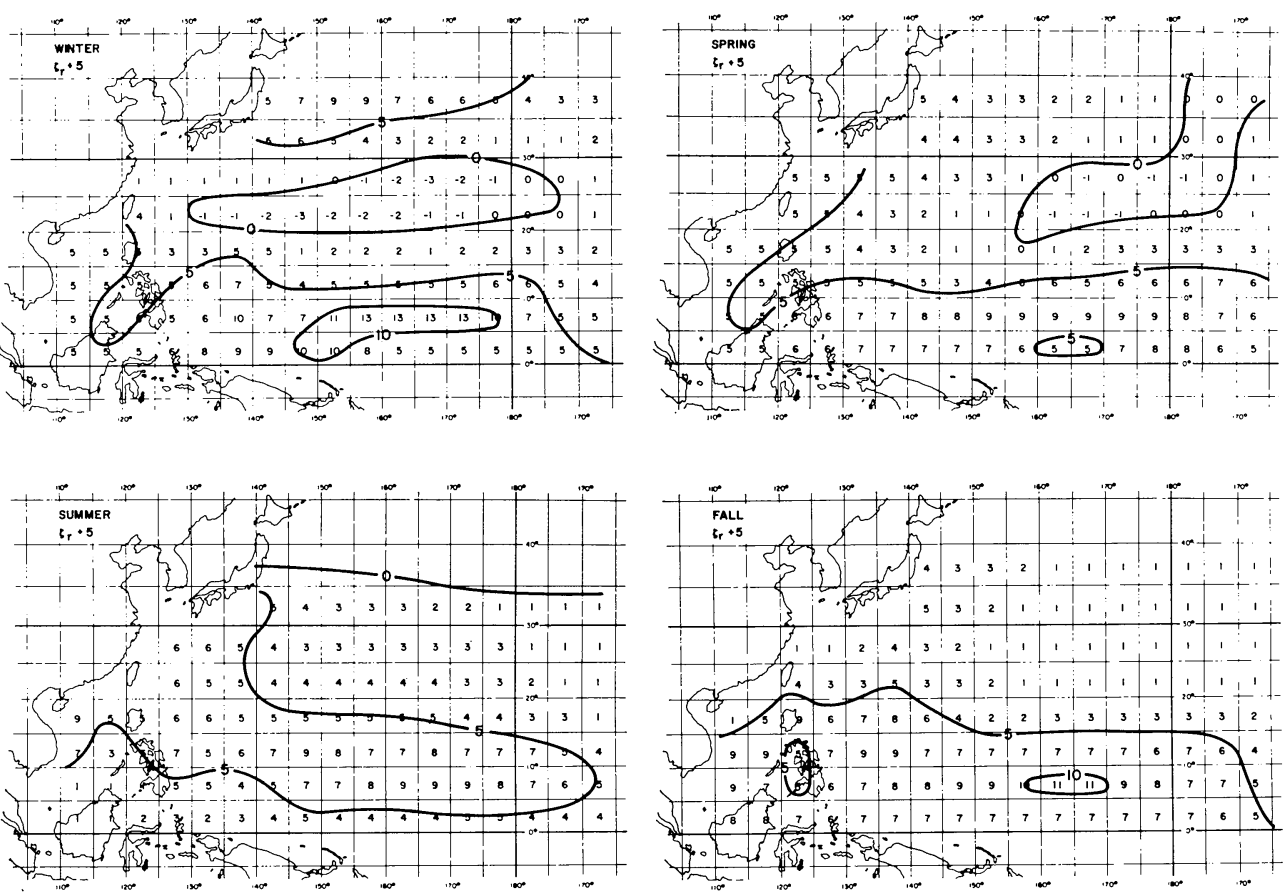

Fig. 7 Seasonal averages of $5^{\circ}$ latitude-longitude square gradient level $(\sim 950 \mathrm{mb})$ relative vorticity $\left(Z_{r}\right)$ in units of $10^{-6} \mathrm{sec}^{-1}$ plus 5 units. Winter is January-March, Spring. is April-June, etc.
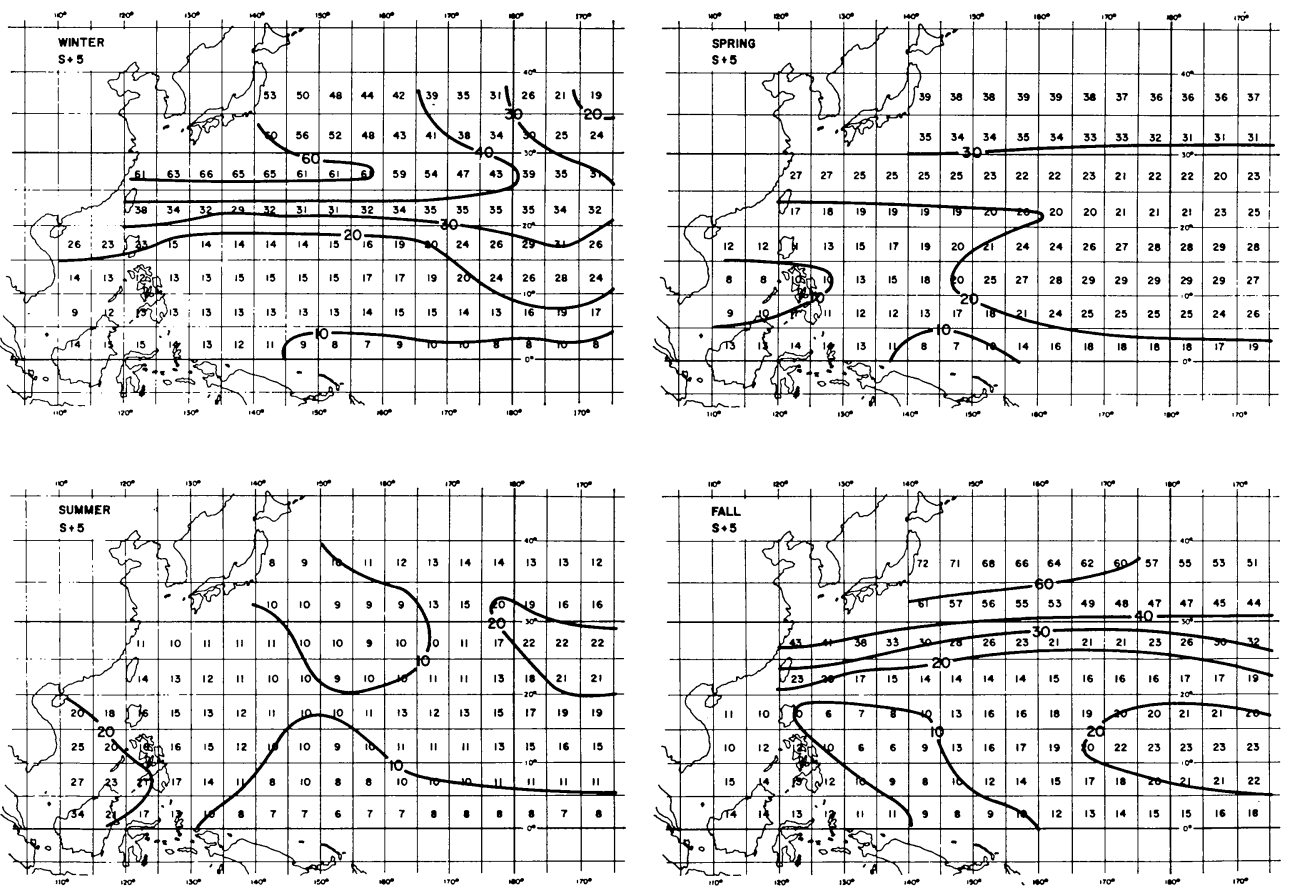

Fig. 8 Seasonal averages of $5^{\circ}$ longitude-latitude square vertical shear of horizontal wind between 950 and $200 \mathrm{mb}$ in units of $\mathrm{m} / \mathrm{sec}$ plus 5 arbitrary units. 
boundary layer frictional dissipation. Other conditions being favorable and remaining constant, tropical cyclone genesis should be directly related to the strength of the Coriolis parameter.

\subsection{Role of Tropospheric Vertical Wind Shear and Ventilation}

As previously discussed by the author (Gray, 1968) the observational evidence clearly shows that tropical cyclones form under conditions of minimum vertical shear of the horizontal wind between the lower and upper troposphere. The individual level cluster winds $(V)$ may be quite different than that of the cluster or disturbance velocity $\left(\boldsymbol{V}_{d}\right)$. The magnitude of $\left(\boldsymbol{V}-\boldsymbol{V}_{d}\right)$ determines the extent to which sensible heat and water vapor are advected, or ventilated, through the developing tropical disturbance.

As discussed by Zehr (1976), ventilation in the upper levels tends to remove sensible heat, while low level ventilation primarily dries the cluster increasing cooling due to re-evaporation of liquid water. Both processes inhibit the enthalpy buildup required for genesis. If ventilation is small, an upper level enthalpy increase can occur. This will lead to gradual surface pressure decreases and cyclone formation. Once a cyclone has formed, the environmental motion relative to the system becomes very small and further enthalpy and moisture gain can be readily accomplished.

Other conditions being favorable and remaining constant cyclone genesis potential should be inversely related to the magnitude of the cloud cluster ventilation. This ventilation is closely correlated to the vertical shear of the horizontal wind between 950 and $200 \mathrm{mb}$. Figure 8 gives western Pacific seasonal values of the magnitude of $950 \mathrm{mb}$ to $200 \mathrm{mb}$ vertical shear of the horizontal wind in $\mathrm{m} / \mathrm{sec}$ plus 5 units.

\subsection{Role of Ocean Temperature}

As previously discussed by Jordan (1964), Landis and Leipper (1968), Leipper (1967), Leipper and Jensen (1971), Leipper and Volgenau (1972), Heffernan (1972), and Perlroth (1967, 1969) tropical cyclones can have a profound influence on the temperature of the ocean over which they travel. The altered ocean temperature, in turn, can feed back and alter the character of the cyclone.

Leipper and his research group have indicated that the inner region of the average hurricane consumes about $4000 \mathrm{cal} / \mathrm{cm}^{2}$ per day of ocean sensible and latent heat energy. In their study of the hurricane boundary layer Malkus and
Riehl (1960) put this value at $\sim 3100 \mathrm{cal} / \mathrm{cm}^{2}$ per day over the inner $90 \mathrm{~km}$ radius of the storm. Whitaker's (1967) calculations for Hurricane Betsy indicate a value of about $3700 \mathrm{cal} / \mathrm{cm}^{2}$ per day. These estimates seem rather high. Frank (1977) has estimated sea surface to air energy fluxes of about $1470 \mathrm{cal} / \mathrm{cm}^{-2} \mathrm{day}^{-1}$ based on composited N.W. Pacific typhoon data. Nevertheless, tropical cyclones have large surface energy requirements which preclude their existence over land or over the ocean if these transfers should somehow be suppressed. Brand (1971) has discussed how typhoons can weaken when they cross the track of a previous typhoon which has produced a cooler sea surface temperature due to upwelling.

The tropical cyclone's cyclonic wind circulation causes oceanic upwelling near the storm's center. The wind circulation produces a cyclonic circulation which is not balanced by an equivalent upward and outward slope of water surface. The reduced air pressure at the storm's center may even cause a slight rising of the inner core ocean surface. Oceanic divergence develops as a consequence resulting in upwelling within and around the cyclone center (Black and Mallinger, 1971). If the ocean has only shallow warm water, cold water upwelling will cool the sea surface and the ocean will not be able to transfer the required energy to the air. Surface air temperatures will decrease. The potential moist instability of the inner cyclone wall will also be much reduced. O'Brien and Reid (1967) and O'Brien (1967) have provided numerical conformation of these central hurricane upwelling physical arguments. Leipper and his colleagues have provided observational arguments.

Leipper and Perlroth have indicated that the influence of hurricanes on the ocean underneath them can extend down to about 200 feet. Given the well established criteria of surface air temperature being above $26^{\circ} \mathrm{C}$, or $79^{\circ} \mathrm{F}$ (Palmén, 1948) a Sea Temperature Factor (STF) is proposed and defined as

$$
\mathrm{STF}=\frac{\left(T-79^{\circ} \mathrm{F}\right)}{1+\left(T_{S S T}-T_{200} \mathrm{ft}\right)}
$$

where $T_{S S T}=$ Sea Surface Temperature in ${ }^{\circ} \mathrm{F}$

$T_{200} \mathrm{ft}=$ Sea Temperature at 200 feet depth in ${ }^{\circ} \mathrm{F}$

This parameter combines the joint requirements for ocean temperature being above $79^{\circ} \mathrm{F}$ and for warm water to be present down to depths of 200 feet. Figure 9 portrays seasonal values of 

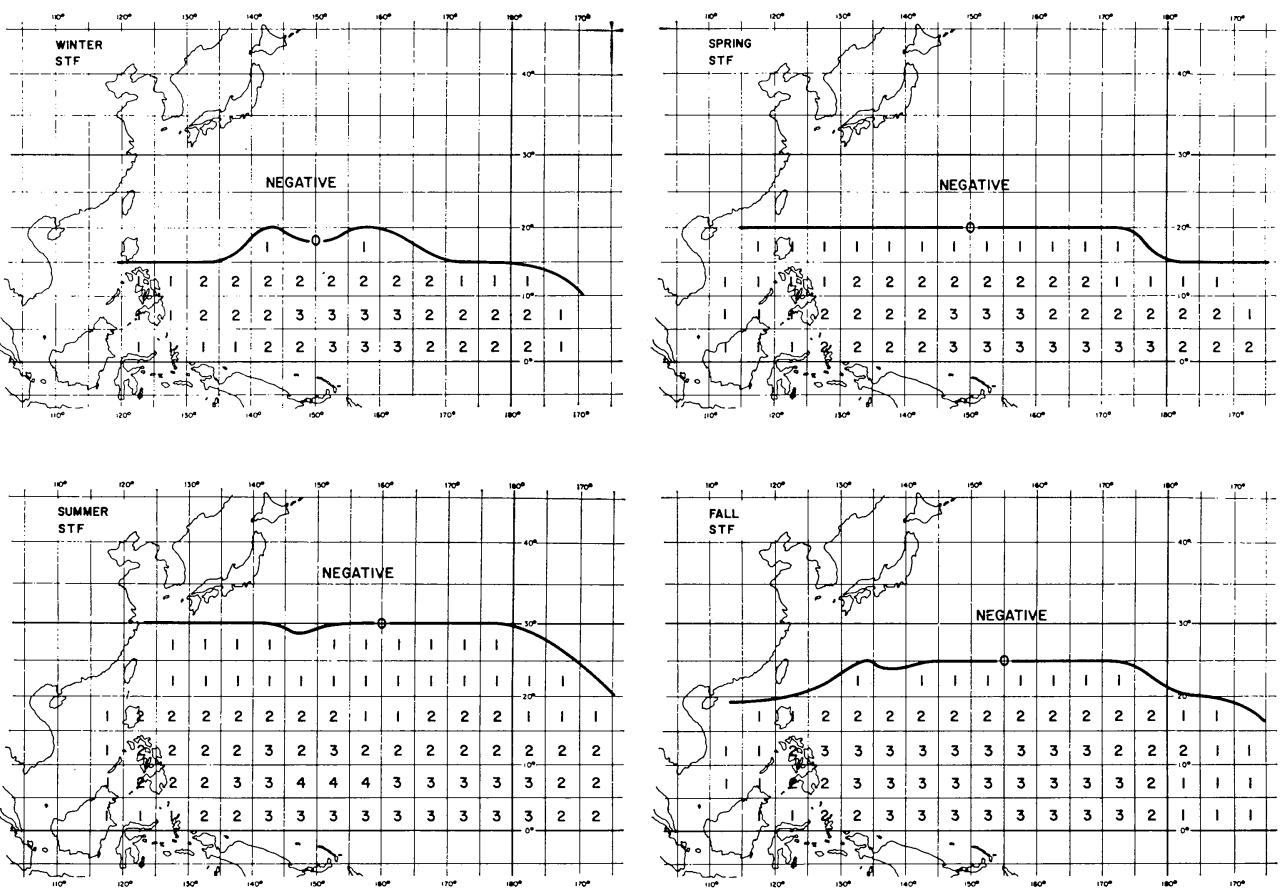

Fig. 9 Seasonal average of $5^{\circ}$ square Sea Temperature Factor (STF) or $\left(T_{S S T}-79^{\circ} \mathrm{F}\right) /$ $1+\left(T_{S S T}-T_{200 f t}\right)$ where $T_{S S T}$ and $T_{200}$ are the sea temperature at the surface and at $200 \mathrm{ft}$ respectively, in ${ }^{\circ} \mathrm{F}$.
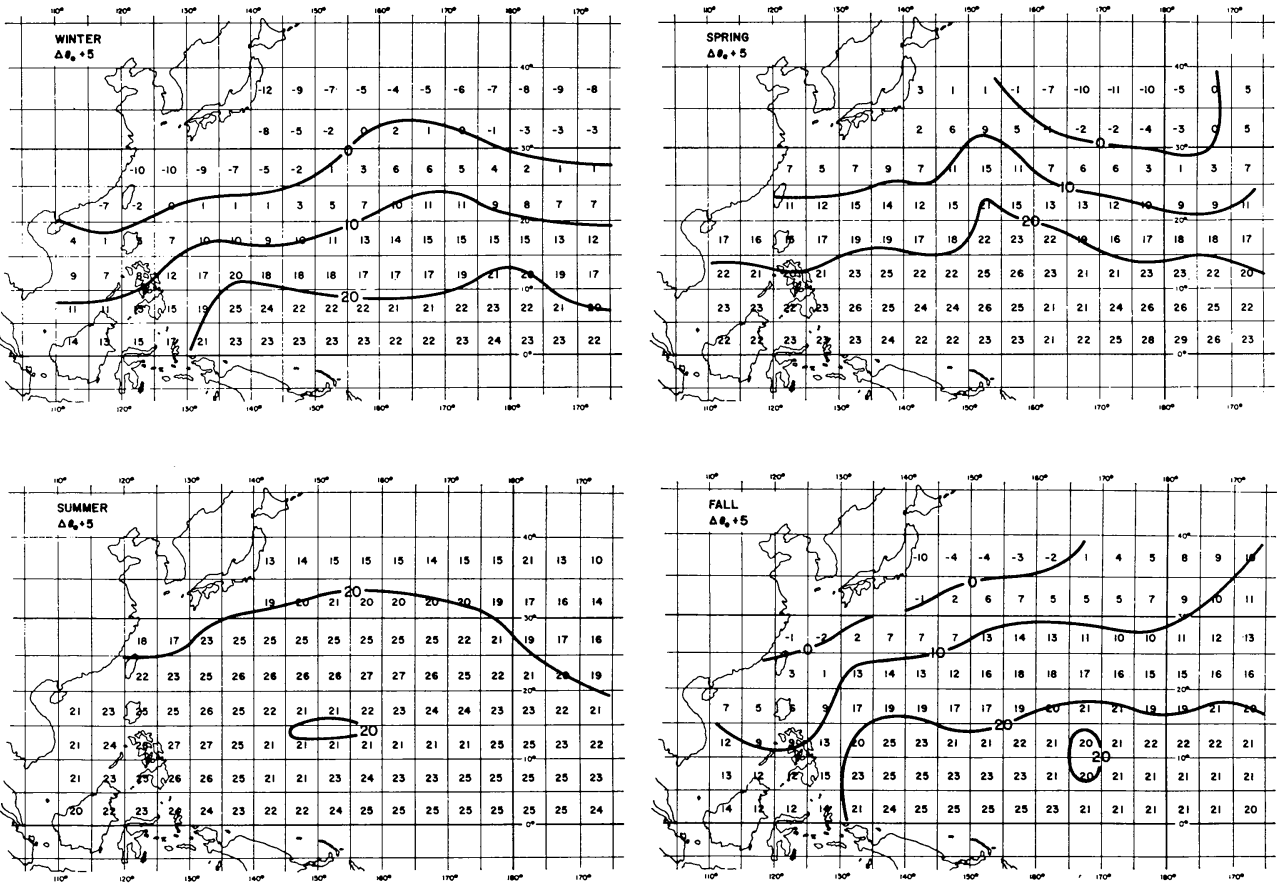

Fig. $105^{\circ}$ square seasonal values of the vertical gradient of $\theta_{e}\left(\Delta \theta_{e}\right)$ between the surface and $500 \mathrm{mb}$ in units of ${ }^{\circ} \mathrm{K}$ plus 5 . 
this factor.

Other conditions being favorable and remaining constant, tropical cyclone genesis should be directly related to the magnitude of the Sea Temperature Factor (as here defined).

\subsection{Role of Surface to Middle Troposphere $\theta_{e}$ Gradient}

Except when there is deep cumulus convection to produce vertical coupling, the flow features of the tropical upper and lower troposphere appear to operate independently (Riehl, 1954). Tropical cyclone circulations, however, extend through the entire troposphere. Cyclones do not occur unless there is a well established vertical coupling of the lower and upper tropospheric flow patterns. Cumulonimbus convection acts as the primary mechanism for this vertical coupling.

$\mathrm{Cb}$ convection requires substantial conditional instability for boundary layer air raised to the middle troposphere. Although potential buoyancy is not strictly specified by vertical gradients of $\theta_{e}$ it is observed that large values of $\partial \theta_{e} / \partial p$ are usually associated with strong conditional instability. A number of other researchers such as Aspliden (1971) have discussed the characteristics of the vertical gradient of $\theta_{e}$ over the tropical oceans with different types of convection. For convenience and following the author's previous paper (Gray, 1968) $\theta_{e}$ gradients are taken between the surface and $500 \mathrm{mb}$. These values typically range between $15-20^{\circ} \mathrm{K}$. Figure 10 gives seasonal values of this parameter plus 5 units. Except in subtropical latitudes in winter, the values of this parameter are usually adequate for cyclone development. Daily parameter deviations are small and typically not well related to cyclone genesis potential. The vertical gradient of $\theta_{e}$ is closely related to the sea temperature factor and middle level humidity parameters.

Other conditions being favorable cyclone genesis should be directly related to the moist buoyancy potential of boundary layer air raised to the middle troposphere. This buoyancy is well specified by the $\theta_{e}$ difference between the surface and the $500 \mathrm{mb}$ level.

\subsection{Role of Middle Troposphere Humidity}

Although deep and intense $\mathrm{Cb}$ convection occurs over middle latitude land areas in conditions of low middle level relative humidity, $\mathrm{Cb}$ convection does not typically occur over ocean regions when middle level humidity is less than 50-60 percent (Ruprecht and Gray, 1976). Over tropical oceans high middle level vapor content appears to enhance deep cumulus convection by reducing entrainment drying of the updraft.

High middle level humidity also leads to in-
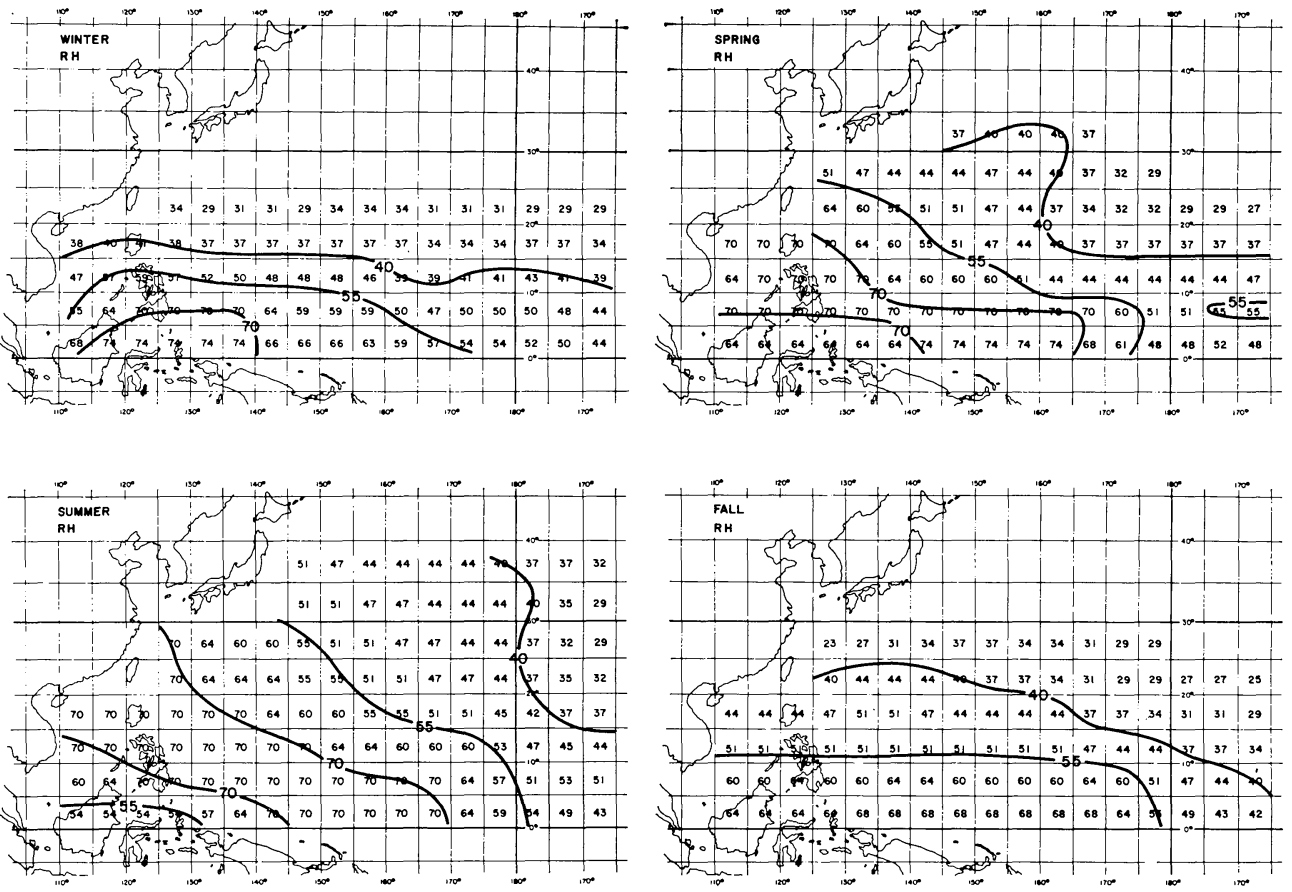

Fig. 11 Seasonal average of $5^{\circ}$ square 500 to $700 \mathrm{mb}$ average relative humidity. 
creased precipitation efficiency and the greater likelihood of enthalpy increase. Lopez's (1973) model of the cumulus life cycle indicates a direct relationship between cumulus induced precipitation at the ground and upper level relative humidity. When upper level humidity is low, much of the cumulus induced condensation does not fall to the ground but is re-evaporated. This produces upper level cooling which can act to suppress rather than enhance the cluster's enthalpy increase.

It is thus assumed that cyclone genesis is directly related to the average of 500 and $700 \mathrm{mb}$ relative humidity. Seasonal values of middle level humidity are used in the form of a humidity parameter which varies from 0 to 0.5 . Cyclone development is not possible if seasonal 500 $700 \mathrm{mb}$ humidity is less than 40 percent so the humidity parameter increases linearly from 0 for seasonal humidity $\leq 40 \%$ to 0.5 for seasonal humidity $\geq 70 \%$. Thus, the RH factor is specified as

$$
\begin{aligned}
& 0.5 \text { for } \mathrm{RH} \geq 70 \% \\
& 0.4 \text { for } \mathrm{RH} 55-69 \% \\
& 0.2 \text { for } \mathrm{RH} 46-54 \% \\
& 0.05 \text { for } \mathrm{RH} 40-45 \% \\
& 0.0 \text { for } \mathrm{RH}<40 \%
\end{aligned}
$$

Figure 11 portrays seasonal values of 500$700 \mathrm{mb}$ relative humidity.

Other conditions being favorable and remaining constant, tropical cyclone genesis frequency should be directly related to seasonal values of middle tropospheric humidity. The relationship between middle level moisture and cyclone genesis is expressed by the above relative humidity factor.

\section{Specification of Seasonal Genesis Frequency}

It is hypothesized that tropical cyclone formation will be most frequent in the regions and in the seasons when the product of the six primary genesis parameters just discussed are a maximum. Zero and negative values of the genesis parameters indicate no genesis potential.

There is some difficulty with using these seasonal values directly. Seasonal values are not a close measure of what the daily parameter values can be. Thus, the seasonal relative vorticity in the sub-tropical regions can be slightly negative. The above seasonally determined genesis potential would not predict cyclone genesis in a region where it sometimes occurs. When the seasonal vaiues of $\left|\partial V_{h} / \partial p\right|$ are small, unreasonably large values of $1 / S_{z}$ are obtained, which are not repre- sentative of the average of the daily values. Similarly the seasonal values of $\partial \theta_{e} / \partial p$ between the surface and $500 \mathrm{mb}$ could be zero or negative, but individual time period values can be positive.

To cover the range of possible daily deviations of three of these parameters, arbitrary units were added to the seasonal values. Thus, five units of $10^{-6} \mathrm{sec}^{-1}$ vorticity were added to all the seasonally measured values of this parameter and $5^{\circ} \mathrm{K}$ were added to all the seasonal values of $\partial \theta_{e} / \partial p$. To prevent unreasonably large values of the genesis frequency when $\left|\partial \boldsymbol{V}_{h} / \partial p\right|$ approaches zero, $5 \mathrm{~m} / \mathrm{sec}$ was arbitrarily added to all the seasonal vertical shear values. The mini-

\begin{tabular}{|c|c|c|}
\hline $\begin{array}{l}\text { Seasonal } \\
\text { Genesis } \propto \\
\text { Parameter }\end{array}$ & $\begin{array}{l}\text { Vorticity } \\
\text { Parameter }\end{array}$ & $\begin{array}{l}\text { Coriolis } \\
\text { Parameter }\end{array}$ \\
\hline $\begin{array}{l}\text { Vertical Shear } \\
\text { Parameter }\end{array}$ & \multicolumn{2}{|c|}{$\begin{array}{l}\text { Sea Temperature } \\
\text { Factor }\end{array}$} \\
\hline $\begin{array}{l}\text { Moist Stability } \\
\text { Parameter }\end{array}$ & $\begin{array}{l}\text { Humid } \\
\text { Parame }\end{array}$ & \\
\hline
\end{tabular}
mum value of the vertical shear parameter is thus 5 units.

A Seasonal Genesis Parameter is now defined as

where $\begin{aligned} \text { Vorticity } & =\left(Z_{r}+5\right), \text { where } Z_{r} \text { is determined } \\ \text { Parameter } & \text { in units of } 10^{-6} \mathrm{sec}^{-1} .\end{aligned}$
Coriolis $=f$ or $2 \Omega \sin \varphi$, where $\Omega$ is the rotation rate of the earth and $\varphi$ denotes latitude.

$\begin{array}{ll}\text { Vertical Shear } & =1 /\left(S_{z}+5\right) \text { where } S_{z}=\left|\partial V_{h}\right| \\ \text { Parameter } & \partial p \mid \text { is determined in units } \\ & \text { of } \mathrm{m} / \mathrm{sec} \text { per } 750 \mathrm{mb} .\end{array}$

Sea Temperature
Factor

Moist Stability $=\partial \theta_{e} / \partial p+5$ where $\partial \theta_{e} / \partial p$ is $\begin{array}{ll}\text { Parameter } & =\partial \theta_{e} \partial p+5 \text { where } \partial \theta_{e} / \partial p \text { is } \\ & \text { in units of }{ }^{\circ} \mathrm{K} \text { per } 500\end{array}$ $\mathrm{mb}$.

Humidity
Parameter $\overline{R H}$ which varies from $0-0.5$. $\overline{R H}=0.5$ for mean $700-500$ mb humidity $\geq 70 \%, 0.4$ for mean humidity of $55-60 \%$, 0.2 for humidity of $46-54 \%$, 05 for humidity of $40-46 \%$ and 0 for values $40 \%$.

This Seasonal Genesis Parameter may also be thought of in the form of

Seasonal
Genesis $=$
Parameter
$\quad \times($ Thermal Potential $)$



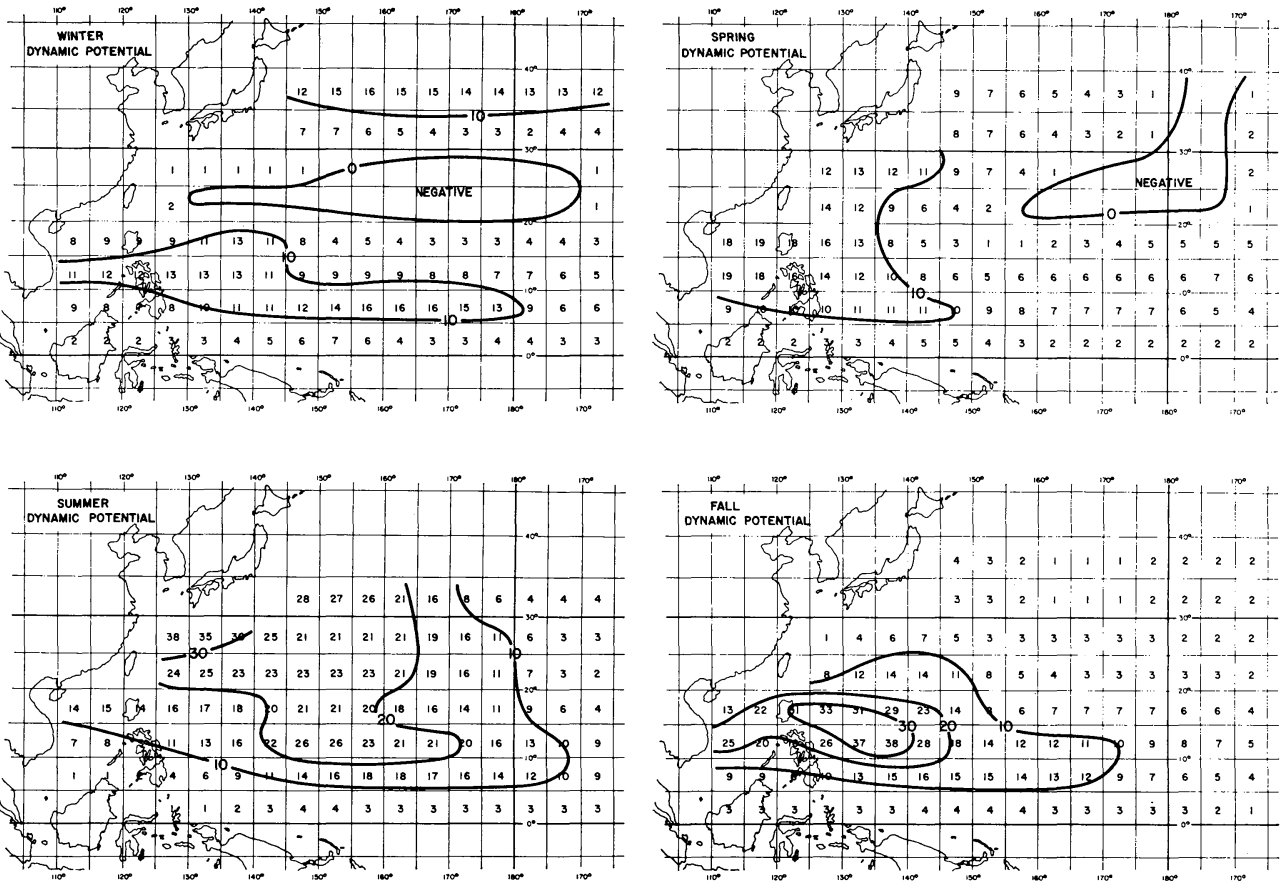

Fig. 12 Seasonal average of $5^{\circ}$ square Dynamic Potential or $\left(Z_{r}+5\right)(f)\left(1 /\left[S_{z}+5\right]\right)$ in units of $\left(10^{-12} \mathrm{sec}^{-1 / \mathrm{m}} / \mathrm{sec}\right.$ per $\left.750 \mathrm{mb}\right)$.
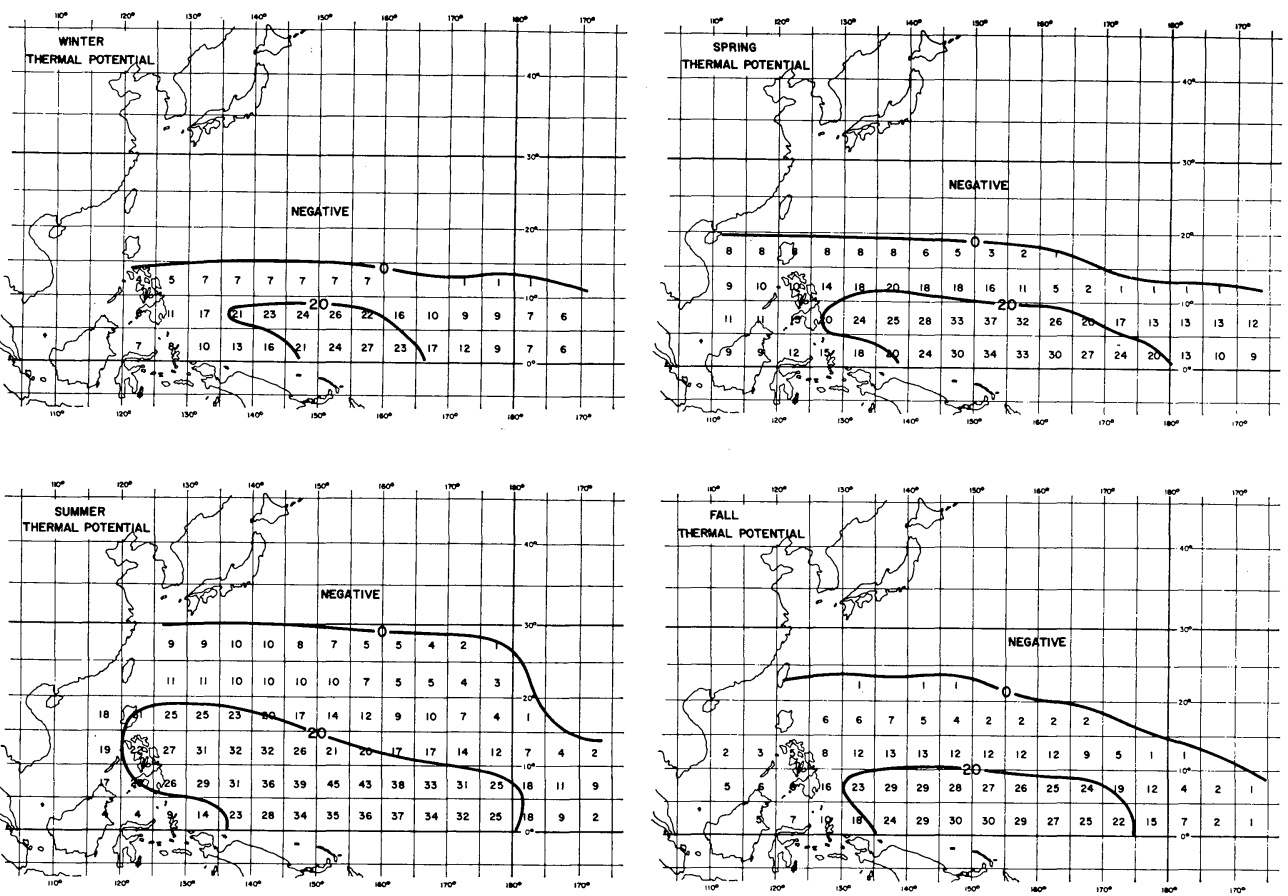

Fig. 13 Seasonal values of $5^{\circ}$ square Thermal Potential or $\left(\left(\Delta \theta_{e}+5\right) \times(\mathrm{STF}) \times(\mathrm{RH}\right.$ factor $)$ in units of ${ }^{\circ} \mathrm{K}$ per $500 \mathrm{mb}$. 
where

$$
\text { Dynamic potential }=\left(Z_{r}+5\right)(f) 1 /\left(S_{z}+5\right)
$$$$
\text { Thermal Potential }=(\mathrm{STF})\left(\partial \theta_{e} / \partial p+5\right)
$$

\section{( $\overline{R H}$ Parameter)}

Dynamic Potential. Seasonal values of the dynamic potential or $\left(Z_{r}+5\right)(f)\left(1 /\left(S_{z}+5\right)\right)$ in units of $10^{-12} \mathrm{sec}^{-2}$ per $\mathrm{m} / \mathrm{sec}$ per $750 \mathrm{mb}$ are portrayed in Fig. 12. The correlation between high values of this potential and the location and frequency of seasonal cyclone genesis is overall rather good, but a number of shortcomings still exist. Cyclone frequency is related to more than dynamic influences. Thermal cumulus buoyancy considerations must also play an important role.

Thermal Potential. Figure 13 gives seasonal values of the product of the Sea Temperature Factor (STF)-Fig. 9, the moist stability $\left(\partial \theta_{e} /\right.$ $\partial p+5)$-Fig. 10, and relative humidity factor derived from the humidity values in Fig. 11. Isolines are portrayed in values of ${ }^{\circ} \mathrm{K}$ per $500 \mathrm{mb}$. This product may be considered as the thermal potential, or the potential for $\mathrm{Cb}$ convection. Note the sharp northward cut-off in the sea temperature factor. This potential restricts genesis to latitudes $<15^{\circ}$ in the winter and inhibits genesis poleward of $30^{\circ} \mathrm{N}$ in general. Equatorwards of $15^{\circ}$ the sea temperature factor is favorable in all seasons.

The moist stability parameter $\left(\partial \theta_{e} / \partial p+5\right)$ is generally large in all oceanic locations except in the sub-tropical latitudes in winter. Cyclone genesis will not generally occur when the magnitude of this parameter is less than 15 . When above 15 , variations of this parameter do not greatly affect spatial and seasonal variations of genesis. Seasonal variation of the 15 line rather well specifies the poleward extent of cyclone genesis.

Seasonal values of the humidity parameter are also very important in specifying the spatial and seasonal frequency of cyclone genesis. Cyclones do not form in regions where the seasonal 500$700 \mathrm{mb}$ relative humidity is less than 40 percent. This parameter is a major factor in specifying differences in winter and summer cyclone frequency at low latitudes.

Verification. Figure 14 portrays seasonal values of the (Dynamic Potential) $\times($ Thermal Potential) or the forecast potential in units of $1.5 \times 10^{-10} \mathrm{sec}^{-2}{ }^{\circ} \mathrm{K}$ per $\mathrm{m} / \mathrm{sec}$. When expressed in these units, the forecast potential is the right
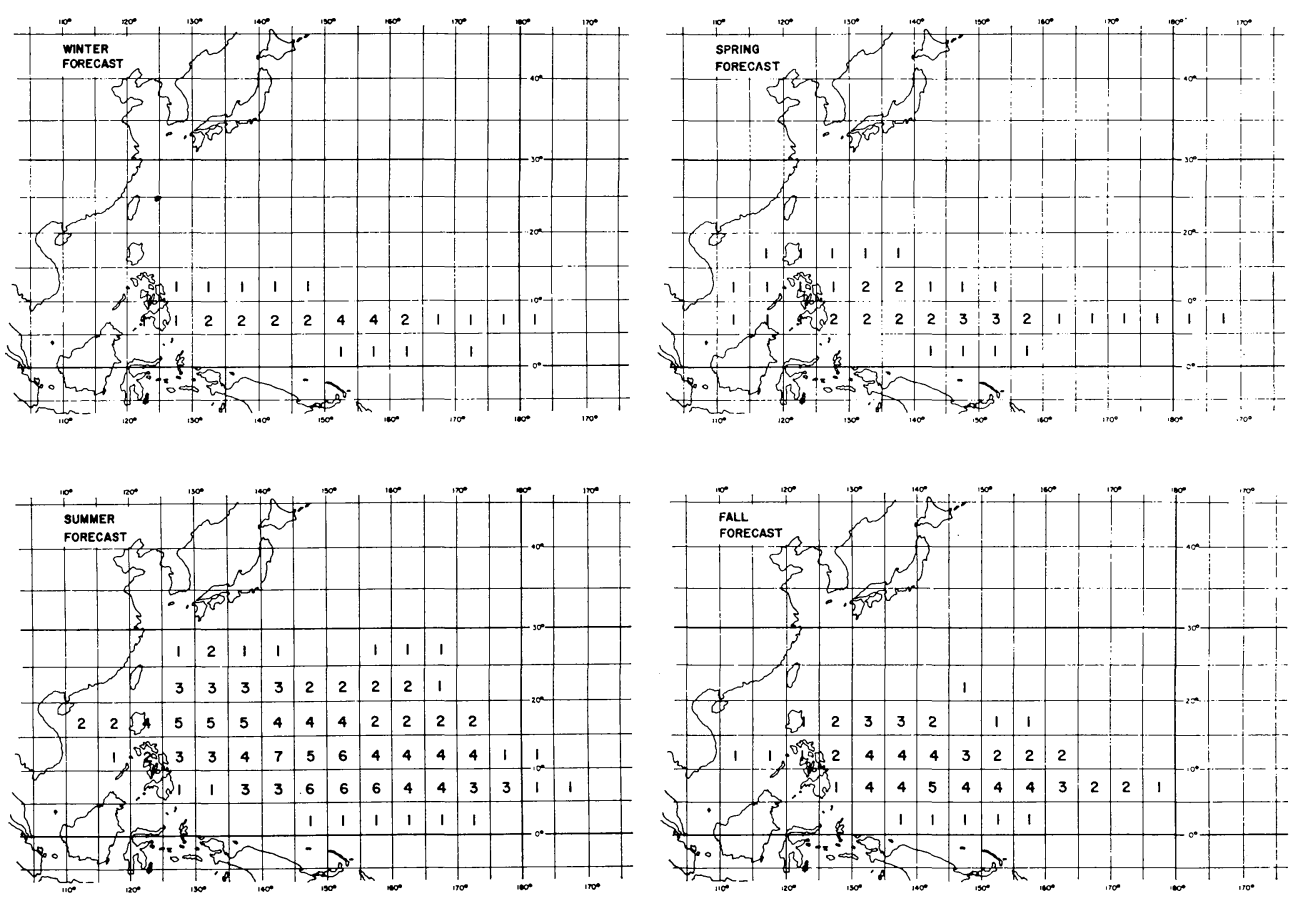

Fig. 14 Seasonal average of $5^{\circ}$ square forecast potential or (Dynamic Potential) $\times($ Thermal Potential) in units of $1.5 \times 10^{-10} \mathrm{sec}^{-2}{ }^{\circ} \mathrm{K}$ per $\mathrm{m} / \mathrm{sec}$. Values shown are of cyclone forecast number per $5^{\circ}$ Marsden square per 10 years. 

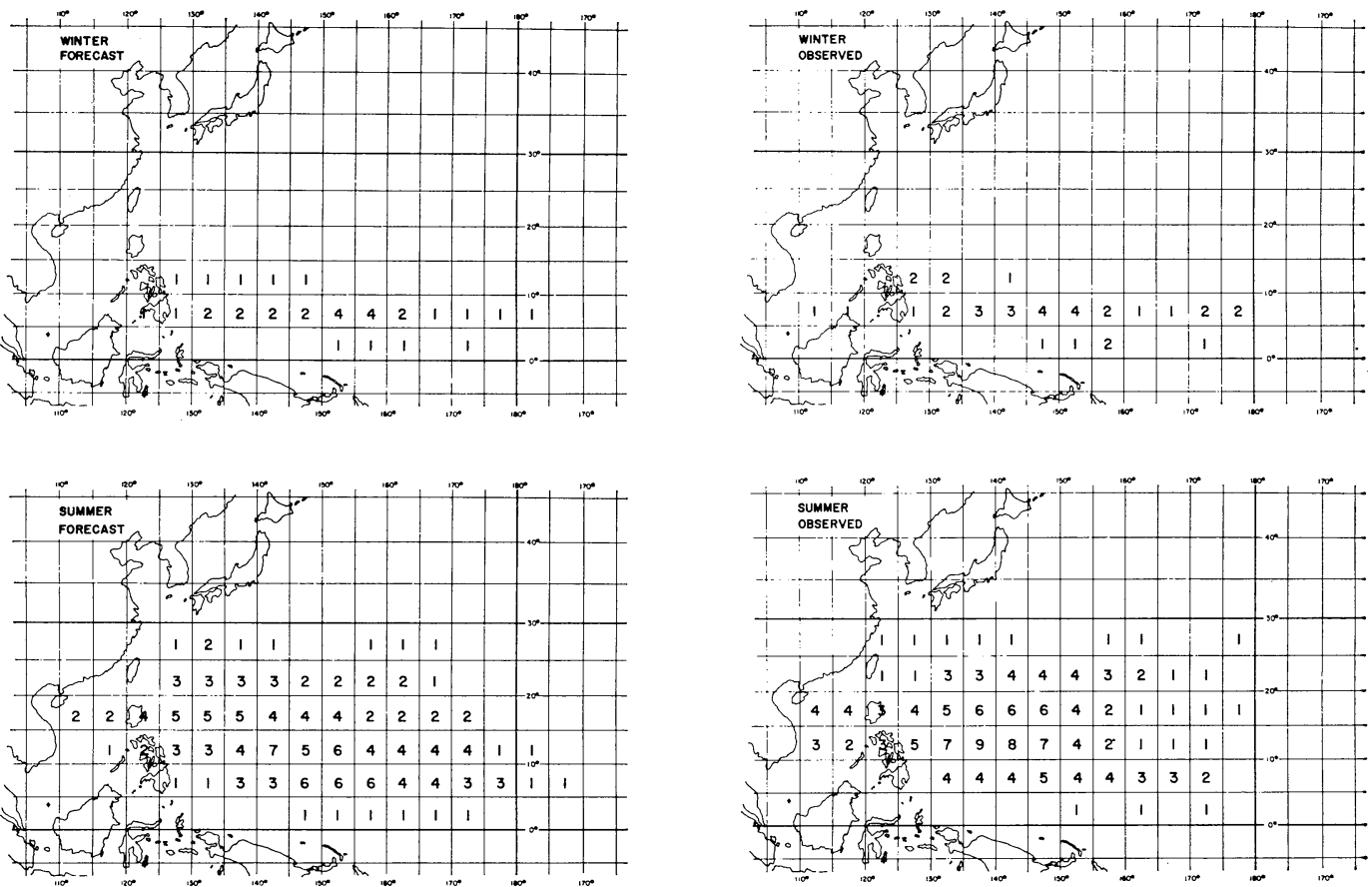

Fig. 15 Comparison of forecast (left) and observed (right) number of tropical cyclone initial genesis points per $5^{\circ}$ Marsden square per 10 years during the winter and summer seasons.
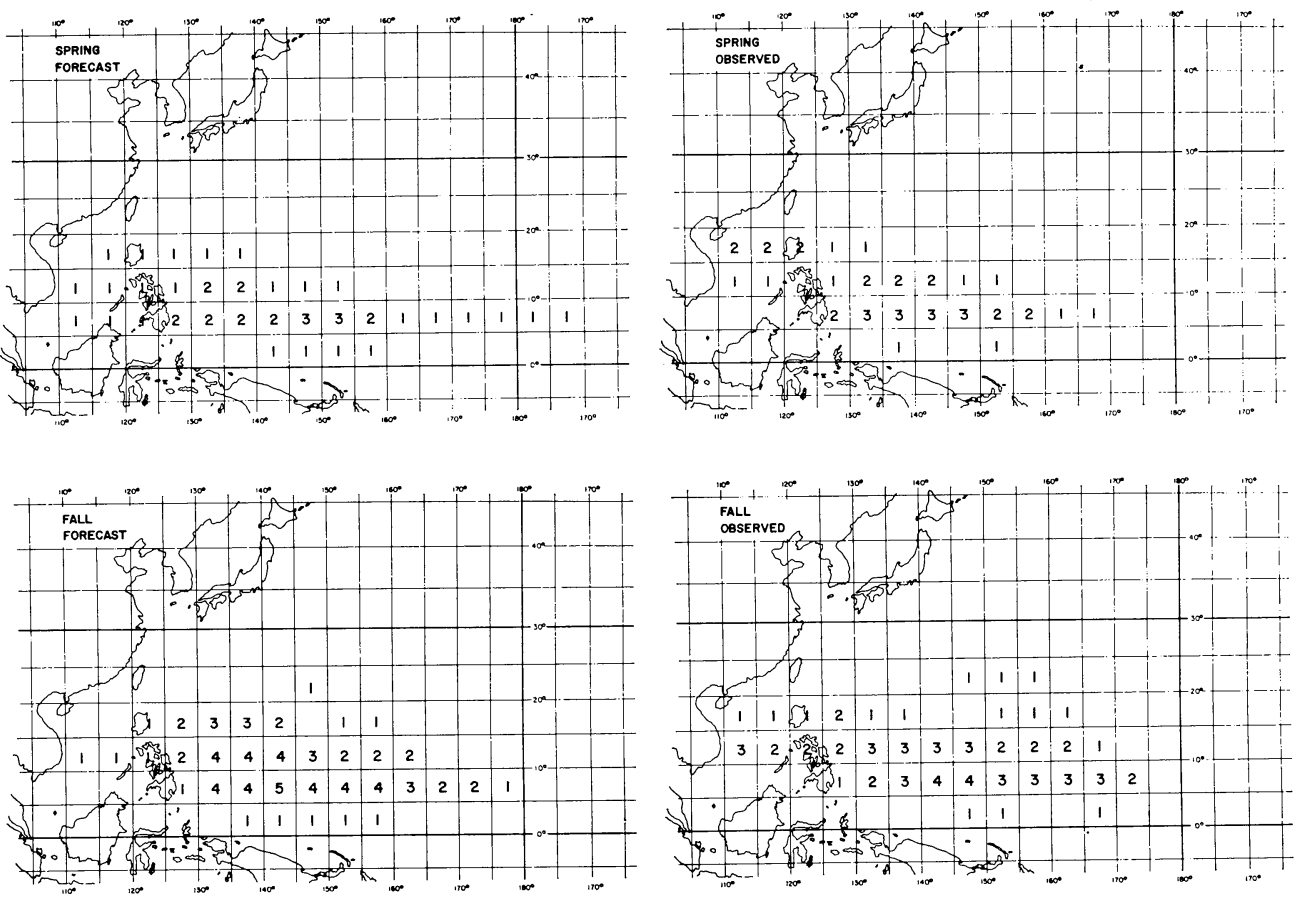

Fig. 16 Comparison of forecast (left) and observed (right) number of tropical cyclone initial genesis points per $5^{\circ}$ Marsden square per 10 years during the spring and fall seasons. 


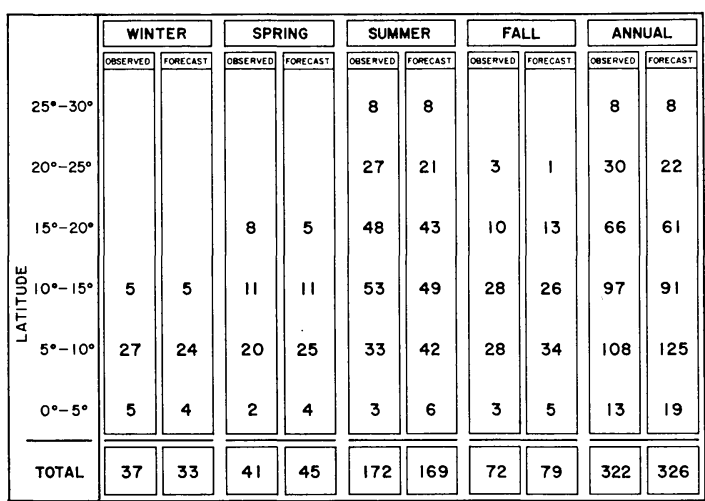

Fig. 17 Comparison of seasonal and annual 10-year total of observed and forecast initial cyclone genesis points by latitude.

magnitude to specify seasonal forecast cyclone genesis frequency in number per $5^{\circ}$ latitudelongitude square per 10 years. A small degree of smoothing has been performed. Figures 1516 compare the forecast and seasonal observed cyclone genesis frequency in number per $5^{\circ}$ square per 10 years. Figure 17 stratifies seasonal forecast potential and observed cyclone genesis by $5^{\circ}$ latitude segments. The very close correspondence between predicted and observed seasonal cyclone frequency lends support to the earlier arguments concerning the relevant physical genesis parameters. It was not expected that the agreement between predicted and observed genesis frequencies would be this close.

It is not just the correlation of these six seasonal parameters with genesis frequency which is noteworthy, but also the physical rationale concerning the effects of these parameters on genesis which is important. It is possible that other climatological parameters can be found which are also related to cyclone frequency, but the author doubts if these other parameters, if detected, can be as well related to the previously discussed physical requirements. A more thorough discussion of this subject is contained in the project report of Gray (1975a).

\section{Discussion}

It is encouraging to learn that the frequencies and spatial distribution of tropical cyclone formation are so closely related to the seasonal climatology. It is hoped that these seasonal genesis statistics can be adapted for use at the various government offices responsible for Western Pacific tropical cyclone monitoring. Even though the dynamics of individual cyclone genesis are very non-linear and unquestionably very complicated, the frequency with which these individual genesis processes are activated is very strongly tied to the large-scale and long-term parameter averages. It was not expected that cyclone frequency could be so closely related to the long term climatological parameters. It is seen that cyclone frequency, although occurring on only a very few days per season, is, nevertheless, directly related to the large scale and long term shifts in the tropical general circulation and thermal energy content.

\section{Acknowledgements}

This research has been supported by a National Science Foundation Research Grant Number (GA-32589X3), with some special assistance in data acquisition from the U.S. Navy Environmental Prediction Research Facility of Monterey, CA. The author is much indebted for the excellent assistance rendered him in data reduction, in calculations, in drafting, and in overall manuscript preparation by Mssrs. Ronald Phelps, Charles Solomon, and by Mrs. Barbara Brumit.

\section{Appendix}

\section{Data Sources for Various Calculations.}

1. Seasonal vorticity was calculated from the monthly gradient level streamline charts of G.D. Atkinson and J.C. Sadler's 1970 report entitled "Mean Cloudiness and Gradient Wind Charts over the Tropics", (Air Weather Service Technical Report No. 215, Vol. II). Vorticity was calculated for each month and then averaged to obtain seasonal mean values.

2. Vertical shear of the horizontal wind from 950 to $200 \mathrm{mb}$ was calculated from the low level data source listed above and from specially constructed $200 \mathrm{mb}$ flow fields for the months of February, May, August, and November which were accomplished by the author at Colorado State University. The constructed $200 \mathrm{mb}$ maps were made from the NOAA Monthly Climatic Data for the World where $200 \mathrm{mb}$ monthly vector winds are listed. It was assumed that the February, May, August and November $200 \mathrm{mb}$ wind vectors were typical of those of the JanuaryMarch, April-June, July-September, and OctoberDecember periods respectively. The vertical shear charts represent the magnitude of the mean wind vector differences between the 200 and $950 \mathrm{mb}$ levels.

3. The Sea Temperature Factor calculations 
were made from the ocean temperature depth data of the North Pacific as reported by Robinson and Bauer (1971).

4. The $\theta_{e}$ gradients between the surface and $500 \mathrm{mb}$ were calculated from monthly values of temperature and moisture from the NOAA Monthly Climatic Data of the World listings for the months of February, May, August, and November. These months were taken as representative of The January-March, April-June, JulySeptember, and October-December seasonal averages.

5. Relative humidity at 500 and $700 \mathrm{mb}$ was obtained from the upper air monthly mean moisture information contained in the NOAA Monthly Climatic Data of the World. This data was adjusted to fit the upper air moisture data contained in the NAVAIR report of Crutcher and Meserve (1970). Some smoothing and reconciliation of these data sources was required, especially in light of the recognized daytime error in humidity reading as discussed by Ruprecht (1975).

6. Initial tropical cyclone genesis location data was obtained from the author's previous report (Gray, 1970) and from undated information listed in the combined U.S. Navy Environmental Prediction Research Facility and the NOAA National Weather Records Center, Asheville, NC, printout tape of tropical cyclone data, position, intensity, etc. This tape was kindly furnished to the author by Mr. Samson Brand of the U.S. Navy's Environmental Prediction Research Facility.

\section{Bibliography of Data Sources}

Atkinson, G. D., and J.C. Sadler, 1970: "Meancloudiness and gradient-level-wind charts over the tropics". Tech. Report 215, II, published by U.S. Air Weather Service MAC).

Crutcher, H. C. and J. M. Meserve, 1970: "Selected level heights, temperatures, and dew points for the northern hemisphere." NAVAIR 50-1C-52, Navy Weather Service Command.

Gray, W. M., 1970: “A climatology of tropical cyclones and disturbances of the western Pacific with a suggested theory for their genesis/maintenancy." NAVWEARSCHFAC Tech. Paper No. 19-70, $224 \mathrm{pp}$.

Robinson, M. K. and R. A. Bauer, 1971: "Atlas of monthly mean sea surface and subsurface temperature and depth of the top of the thermocline, North Pacific Ocean." Monterey Fleet Numerical Weather Central, 72 charts.

Ruprecht, E., 1975: Diurnal temperature corrections for rawinsonde humidity sensors. Mon. Wea. Rev., 103, 352-355.

\section{References}

Aspliden, C. I., 1971: "On energy distribution in the tropical atmosphere Ph.D. Dissertation," Florida State Univ., $232 \mathrm{pp}$.

Black, P.G., and W.D. Mallinger, 1971: "The mutual interaction of Hurricane Ginger and the upper-mixed layer of the ocean." Appendix D, Project Stormfury Annual Report, 1971. National Hurricane Research Laboratory, Coral Gables, FL.

Brand, S., 1971: The effects on a tropical cyclone of cooler surface waters due to upwelling and mixing produced by a prior tropical cyclone. J. Appl. Meteor., 10, 865-874.

Charney, J.C., and A. Eliassen, 1949: A numerical method for predicting the perturbations of the middle-latitude westerlies. Tellus, 1, 38-54.

—, and 1964: On the growth of the hurricane depression. J. Atmos. Sci., 21, 68-75.

Dunn, G. E., 1940: Cyclogenesis in the tropical Atlantic. Bull. Am. Meteor. Soc., 21, 215-229.

- 1951: "Tropical cyclones. Compendium of Meteorology," American Meteorological Society, Boston, MA, 887-901.

Fisher, E. L., 1958: Hurricanes and the sea-surface temperature field. J. Meteor., 15, 328-33.

Frank, W. M., 1977: The structure and energetics of the tropical cyclone, II: Dynamics and energetics. Mon. Wea. Rev., 105, 1136-1150.

Gray, W. M., 1968: Global view of the origin of tropical disturbances and storms. Mon. Wea. Rev., 96, 669-700.

1970: "A climatology of tropical cyclones and disturbances of the western Pacific with a suggested theory for their genesis/maintenancy." NAVWEARSCHFAC Tech. Paper No. 19-70, $224 \mathrm{pp}$.

_- 1975a: "Tropical cyclone genesis." Atmos. Sci. Paper No. 234, Colo. State Univ., Ft. Collins, CO, $121 \mathrm{pp}$.

, 1975b: "Tropical cyclone genesis in the western North Pacific." ENVPREDRSCHFAC Technical Paper No. 16-75, EPRF, Naval Postgraduate School, Monterey, CA, 66 pp.

Heffernan, R. F., 1972: "Hurricane heat potential of the North Atlantic and North Pacific Oceans." M.S. Thesis of the Naval Postgraduate School, Monterey, CA, $109 \mathrm{pp}$.

Hodge, W. T., and G. F. McKay, 1970: "A computer program to select typhoon analogs and print out their descriptions including subsequent changes." NAVWEARSCHFAC Project Order PO-90003 (available from Navy Weather Research Facility, Norfolk, VA) 40 pp. 
Jordan, C. L., 1964: On the influence of tropical cyclones on the sea surface temperature field. Proc. Symp. Tropical Meteorology, Wellington, New Zealand Meteor. Service, 614-622.

Landis, R. C., and D. F. Leipper, 1968: Effects of Hurricane Betsy upon Atlantic ocean temperature, based upon radio transmitted data. J. Appl. Meteor., 7, 544-562.

Leipper, D. F., 1967: Observed ocean conditions and Hurricane Hilda, 1964. J. Atmos. Sci., 24, 182-196.

-, and J. Jensen, 1971: Changes in energy input from the sea into hurricanes. Bull. Am. Meteor. Soc., 52, 928.

- and D. Volgenau, 1972: Hurricane heat potential of the Gulf of Mexico. J. Phy. Ocean. 2, 218-224.

Lopez, R. E., 1973: A parametric model of cumulus convection. J. Atmos. Sci., 30, 1345-1373.

Malkus, J. S., and H. Riehl, 1960: On the dynamics and energy transformation in steady-state hurricane. Tellus, 12, 1-20.

Miller, B. I., 1964: A study of the filling of Hurricane Donna. (1960) over land. Mon. Wea. Rev., 94, 389-406.

O'Brien, J. J., 1967: The non-linear response of a two-layer baroclinic ocean to a stationary, axiallysymmetric hurricane: Part II. Upwelling and mixing induced by momentum transfer. J. Atmos. Sci., 24, 208-215.

-, and R. O. Reid, 1967: The non-linear response of a two-layer baroclinic ocean to a station, axially-symmetric hurricane: Part II. Upwelling and mixing induced by momentum transfer. J. Atmos. Sci., 24, 197-207.

Palmén, E. H., 1948: On the formation and structure of tropical cyclones. Geophysica, Helsinki, 3, 26-38.

, 1957: A review of knowledge on the formation and development of tropical cyclones. Proc. Tropical Symp., Brisbane, December, 1965.

Perlroth, I., 1967: Hurricane behavior as related to oceanographic environmental conditions. Tellus, 19, 258-268.

1969: Effects of oceanographic media on equatorial Atlantic hurricanes. Tellus, 21, 230244.

Riehl, H., 1954: Tropical Meteorology. McGrawHill, New York.
1957-1962: Much personal communication during this period.

Ruprecht, E., and W. M. Gray, 1976a: Analysis of satellite-observed tropical cloud clusters, I: Wind and dynamic fields. Tellus, 28, 391-412.

1976b: Analysis of satellite-observed tropical cloud clouters, II: Thermal, moisture and precipitation. Tellus, 28, 414-425.

Sadler, J. C., 1967a: On the origin of tropical vortices. Working Panel on Trop. Dyn. Meteor. Naval Postgraduate School, Monterey, CA, 3975.

1967b: "The tropical tropospheric trough as a secondary source of typhoons and a primary source of tradewind disturbances." Final Rept. Cont. AF19 (628) 3860, A. F. Cambridge Res. Lab., Bedford, MA. Rept. 67-12, 44 pp. 1974: "A role of the tropical upper tropospheric trough in early seasonal typhoon development." Tech. Paper No. 9-74, ENVPREDRSCHFAC, U.S. Navy Environmental Prediction Research Facility Report. 54 pp.

Sartor, J., 1968: "Monthly climatological wind fields associated with tropical storm genesis in the West Indies." Atmos. Sci. Paper, Colo. State Univ., Ft. Collins, CO, 34 pp.

Wachtmann, R. R., 1968: "Role of angular momentum transport in tropical storm dissipation over tropical oceans." Atmos. Sci. Paper, Colo. State Univ., Fi. Collins, CO, $46 \mathrm{pp}$.

Whitaker, W. D., 1967: "Quantitative determination of heat transfer from sea to air during passage of Hurricane Betsy." M.S. Thesis, Texas A \& M University, College Station, TX, 65 pp.

Williams, K. T., and W. M. Gray, 1973: A statistical analysis of satellite-observed trade wind cloud clusters in the western north Pacific. Tellus, 21, 323-336.

Yanai, M., 1961: A detailed analysis of typhoon formation. J. Meteor. Soc. Japan, 39, 187-214.

, 1964: Formation of tropical cyclones. Reviews Geophys., 2, 367, 414.

- 1968: Evolution of a tropical disturbance in the Caribbean Sea region. J. of Meteor. Soc. of Japan, Series II, 46, 86-108.

Zehr, R., 1976: "Tropical disturbance intensification." Atmos. Sci. Paper No. 259, Colo. State Univ., Ft. Collins, CO, 91 pp. 


\section{西部北太平洋における熱帯低気圧発生}

\section{William M. Gray}

コロラド州立大学, 大気科学教室

著者は近年熱帯低気圧発生の全球的解析をまとめてきた (Gray, 1975a)。この論文ではその研究の結果を西部北太 平洋に打ける熱帯低気圧発生およびその発生位置と頻度の気候学的季節変化の更に詳細な解析に適用する。

この論文の第一の部分では熱帯低気圧発生の季節別頻度についての統計学的知識を提示し発生に対する主な物理学 的条件について討論する。この論文の第二の部分ではこのようにして仮説的に与兄られた発生条件が季節別に平均さ れた六つの気象学的パラメーターの積によっていかに指定されるかを示す。この論文の最後の部分ではこの季節別に 平均されたパラメーターの積が低気圧発生位置と頻度にいかによく関係しているかを示す。低気圧発生予報の一つの インデックスを提唱するものである。 